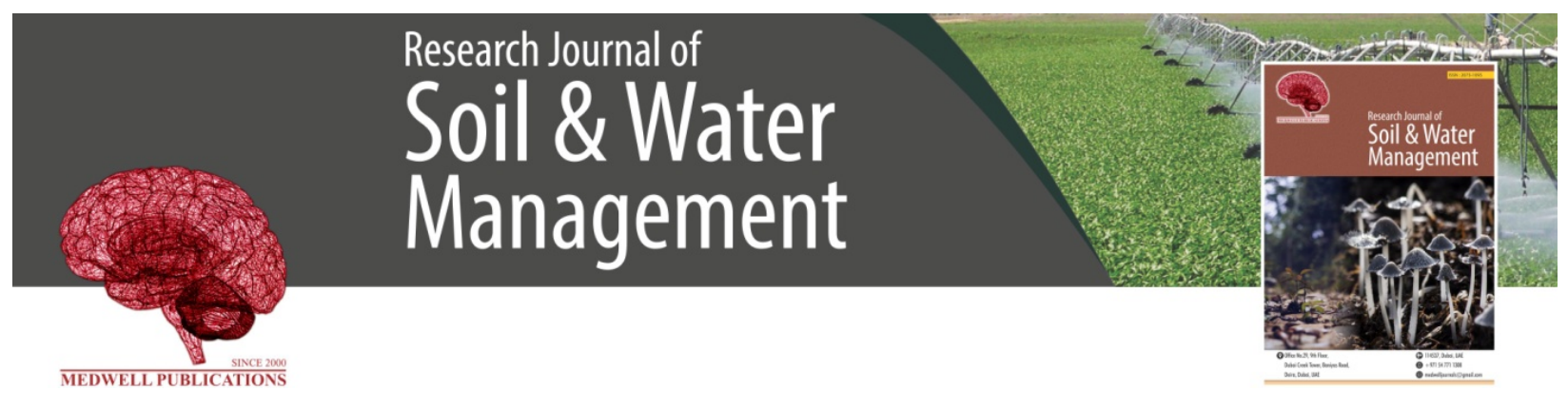

\title{
Adoption of Soil Biodiversity Conservation Measures and Sustainable Agriculture Production in Wakisi and Nagojje Sub Counties, Buikwe District
}

\author{
${ }^{1}$ J.W. Tukamushaba, ${ }^{1}$ B. Mugonola, ${ }^{2}$ A.C. Otieno, ${ }^{3}$ F.W. Bugenyi and ${ }^{1}$ D.L. Kibikyo \\ ${ }^{I}$ Department of Agriculture, Faculty of Agriculture, Science and Technology, Busoga University, P.O. Box \\ 154, Iganga, Uganda \\ ${ }^{2}$ Department of Geography and Social Development, School of Humanities and Social Sciences, Jaramogi \\ Oginga Odinga University of Science and Technology, P.O. Box 210-40601, Bondo, Kenya \\ ${ }^{3}$ Department of Environment, College of Agriculture and Environment, Makerere University, P.O. Box 7062, \\ Kampala, Uganda
}

Key words: Adoption, soil, biodiversity, conservation, sustainable, households, agriculture

\section{Corresponding Author:}

J.W. Tukamushaba

Department of Agriculture, Faculty of Agriculture, Science and Technology, Busoga University, P.O. Box 154, Iganga, Uganda

Page No.: 1-8

Volume: 11, Issue 1, 2020

ISSN: 2075-1095

Research Journal of Soil and Water Management Copy Right: Medwell Publications
Abstract: Human beings are in economic conflict with soil biodiversity for a life struggle. The need for increased food production to match the demand for the ever increasing human population in Uganda has led to agriculture intensification. This however is associated with a high level of ecological disturbance by poor methods of farming that upset the balance of soil biodiversity, especially in Wakisi and Nagojje Sub Counties. A study of 60 households in Wakisi and Nagojje to determine factors affecting adoption of soil biodiversity conservation measures revealed that education and household size (number of active adults in the household) were statistically significant for the adoption rate. Results of the logistic regression model showed that education predisposes farmers to new knowledge and therefore enhances their potential to their adoption while big households are good indicators of labour supply which is vital in labour intensive technologies. Researchers therefore, recommended that farmers should be educated using practical methods to increase literacy about technologies, government should provide incentives to farmers and support organizations that have shown interest in the technologies and that, farmers should always be involved in the technology right from the development stage in order to capture their perceptions about new technologies.

\section{INTRODUCTION}

Agriculture, Uganda's economic back bone is one of the major threats of biodiversity ${ }^{[1]}$. Biodiversity, the diversity of genes, organisms and ecosystems ${ }^{[2]}$ is diminishing attributed to change by human agricultural activities $^{[3]}$. Soil biodiversity which is the variability among living organisms in the soil-ranging from the 
myriad of invisible microbes, bacteria and fungi to the more familiar macro-fauna such as earthworms and termites ${ }^{[4-6]}$ plays a key role in determining soil quality. It is fundamental for agricultural production and food security as well as environmental conservation which human wellbeing depends $\mathrm{on}^{[7,8]}$. Human survival is inextricably linked to the survival of numerous other species on which intact ecosystems depend ${ }^{[7]}$. Therefore, man's war against biodiversity is inevitably war against himself.

Uganda's increasing human population has led to increased pressures on land for settlement and intensification of agriculture which has triggered overgrazing, deforestation and use of inappropriate farming practices ${ }^{[9]}$. In Wakisi and Nagojje Sub Counties, high population pressure and high market demands for a variety of products from Kampala and Jinja has increased encroachment on marginal areas with poor farming practices. These in turn have resulted in general land degradation and soil erosion on the higher slopes. Extensive use of agro chemicals, especially, for horticultural crops has intensified pollution of the soil and water, thus, toxins are being introduced in the food chain and posing danger to health of consumers and other living organisms ${ }^{[10]}$.

Past and current agricultural practices in Wakisi and Nagojje Sub Counties such as charcoal burning, bush burning, mono-cropping, use of synthetic chemicals like herbicides continue to threaten soil biodiversity and even kill them if such chemicals are abused ${ }^{[11]}$. Uganda loses up to $12 \%$ of her natural resources worth over $\$ 500$ million per year due to natural resource degradation. Consequently, forest cover and biodiversity are decreasing due to pressure exerted by the increasing demand for forest products and agricultural expansion $^{[12]}$.

The growing concern about the soil productivity and wider environmental implications of conventional agricultural practices has prompted governments and farmers to explore alternative production methods that maintain soil structure and productivity ${ }^{[13]}$. One of the most significant factors influencing a new ideas or technologies is the degree to which they tailor an innovation to meet the needs and interests of a community ${ }^{[14]}$. It is generally agreed that the natural physical environment, together with social, economic and institutional factors is responsible for the Soil Biodiversity Conservation (SBDC) decision behavior both in the developed and developing world. However, the specific socio-economic and institutional variables affecting decision behavior may differ between developed and developing countries, different sites within the same region and country as well as between different farm households and plots ${ }^{[15]}$.
Research on the adoption of soil biodiversity conservation measures began in the 1950 ' $\mathrm{s}^{[16]}$. The magnitude and direction of influence of different variables vary between different types of conservation practices ${ }^{[15]}$.

Farmer's behavior toward adoption is influenced by social and economic factors. Gender of the respondents, training in soil conservation and per capita income are found to be positively and significantly influential in the adoption of SBC measures ${ }^{[9]}$.

Adoption of soil biodiversity conservation at the farm level is associated with lower labour and farm power inputs, more stable yields and improved soil nutrient exchange capacity. Crop production profitability under SBC tends to increase over time relative to conventional agriculture $^{[17]}$.

The personal and household attributes include factors like education, age, family size, gender among others ${ }^{[18,9]}$. In general, education has been observed to have positive effects on conservation. However, education might offer alternative livelihood opportunities in off-farm activities thereby increasing the opportunity cost of labour and competing with labour use for agricultural production. The attitudes and behaviour of farmers towards certain technologies tend to influence the discrete choice decisions of their neighbours ${ }^{[19]}$.

Financial returns might not be the only or even the major, consideration that provides incentive to subsistence farmers for investment in soil biodiversity conservation. Socio-economic and institutional factors operating from the level of the national economy through the individual farm household all play a strong role in shaping farmer's incentives for SBDC investment ${ }^{[15]}$. Farmers with higher per capita income seem more likely to invest in SBDC than low income farmers. Larger farms and group membership inhibit the adoption of SBDC.

Institutional factors such as land ownership, membership in farmer's organizations and technical assistance have been found in some studies to influence on-farm adoption of conservation practices. Limited resource farmers whose survival depends on the piece of land they operate are more likely to adopt SBDC measures, since, their livelihood depends on the productivity of the land because of limited alternative employment opportunities in the area ${ }^{[18]}$.

Many of the problems in conserving biodiversity are associated with the lack of recognition of the importance it plays in agricultural production. Although, many farmers and the farming community have a profound knowledge of their agriculture, training and education is often needed to highlight the roles of the soil biota at various levels of the ecosystem/landscape (Sustainable crop production intensification, n.d.).

Capacity building for the farmers on appropriate soil biodiversity conservation practices/technologies could 
enhance farmer's knowledge and skills for adoption ${ }^{[11]}$. Farmers should get educated or trained through campaign or adult education to encourage them to realize full potential of good agricultural practices and the majority to be brought on board if adoption of conservation technologies is to be realized ${ }^{[20]}$. The researcher's specific objectives to this study were:

- To determine agricultural practices that conserve soil biodiversity

- To establish the advantages of conserving soil biodiversity in Wakisi and Nagojje Sub Counties

- To determine factors responsible for the low adoption of soil biodiversity conservation measures

- To establish ways of enhancing adoption of soil biodiversity conservation in Wakisi and Nagojje sub counties

Description of study area: Wakisi and Nagojje are two of the 8 Sub Counties of the then Buikwe County in Mukono District but now a District of herself. It is surrounded by Lake Victoria and farming is the major economic activity, especially to small holder farmers. It is about $12 \mathrm{~km}$ East of Kampala city in Central Buganda region ${ }^{[10]}$. Wakisi and Nagojje were purposely chosen because the Makerere University Conservation and sustainable project of below ground biodiversity had been establishing a number of demonstration sites about conservation measures and funded this research.

\section{MATERIALS AND METHODS}

This was a case study conducted through a descriptive survey research design. It was concerned with determining the adoption rate of soil biodiversity conservation measures in Wakisi and Nagojje Sub Counties in Buikwe County Mukono District.

Descriptive approach was used in order to gather information about the present existing condition and utilize observations in the study. The research study partially based its findings through both quantitative research methods in order to permit a flexible and iterative approach. It also employed qualitative research method in order to find and build theories that would explain the relationship of one variable with another variable through qualitative elements in research. A total of 60 respondents were randomly determined using a probabilistic sampling design specifically simple random sampling.

Researchers used both administered questionnaire, interviews, observations and documentary analysis as the main tools for collecting data. They were concerned with views, perceptions, opinions, attitudes and behaviours of the respondents ${ }^{[21]}$. Questionnaires were administered by the interviewer, especially where concepts were difficult to interpret by farmer respondents. The data obtained through a questionnaire was similar to that obtained through an interview because of the open ended questions.

Descriptive statistics for the survey items was summarized in the text and reported in tabular and chart forms. Frequencies analyses were conducted to identify valid percent for responses to all the questions in the survey. To determine factors that could enhance adoption of soil biodiversity conservation measures, a binary logit model was run using Statistical Package for Social Sciences (SPSS) Version 21.0.

\section{RESULTS AND DISCUSSION}

Socio-demographic characteristics of respondents: The socio-demographic characteristics of respondents were tabulated from questionnaires describing bio-data, education background and occupation of respondents in the study area (Table 1).

Table 1: Socio-demographic characteristics of respondents $(\mathrm{N}=60)$ Characteristics Frequencies Percentage

Age

$10-19$

20-29

30-39

40-49

$50-59$

$\geq 60$

Gender

Male

Female

Marital status

Single

Married

Divorced

Widowed

Dependants

$1-5$

6-10

11-15

Highest education level

Primary

O' level

A' level

College/University

Never to school

Land ownership

Customary

Land lease

Free hold

Land size (ha)

1-5

6-10

$\geq 11$

Farming experience (Years)

1-9

10-19

20-29

30-39

$\geq 40$

Household leader

Male spouse

Female spouse
3.3

21.7

33.3

18.3

13.3

10.0

48.3

51.7

3.3

80.0

8.3

8.3

30.0

61.7

8.3

53.3

25.0

0.0

8.3

13.3

43.3

28.3

28.3

86.7

8.3

5.0

21.7

33.3

20.0

15.0

10.0

81.7 18.3 
About $58.4 \%$ of household respondents were between 10-39 years which suggests that farming has become an occupation for the youth. As seen in Table 1 above, $48.3 \%$ were male while $51 \%$ were female which is a fifty-fifty situation that indicates an equal understanding between man and women in decision making.

More than a half of respondents were female (51.7\%) indicating gender sensitivity and farming dominance by female. Over $3 / 4$ of respondents were married $(80 \%)$ and had over six dependants (70.1\%) (Table 1). This indicates that the most of households acquire responsibility through marriage that stimulate them to join farming to produce food to survive their household members and generate income to help them fulfill their needs and responsibilities ${ }^{[22]}$. Also, these large households are able to provide labour required to implement the technology ${ }^{[29]}$.

Over three quarters of household respondents $(86.6 \%)$ attended formal education. This shows that they had the capacity to attend seminars intended to educate and sensitize them about new technologies and implement them effectively.

Over $3 / 4$ of farmers had land ranging from $1-5$ hectares indicating such a small land that cannot be allowed to rest under fallow. This land is obtained through customary ownership (43.3\%), land lease (28.3\%) and free hold (28.3\%). This shows that culture plays an important role in the agriculture sector. This is manifested by the majority of household respondents whose occupation was farming with over 10 year's experience (78.3\%) (Table 1). This further indicates that most famers have got the ability to decide and adapt new agricultural technologies that seem to help them.

Soil biodiversity conservation measures: About $66.7 \%$ of farmers didn't have any idea about soil biodiversity. $33.3 \%$ knew some soil living organisms like termites, rodents but not the subject matter. Over a half percent of respondent farmers did not even know the advantages of soil living organisms (53.3\%) and their disadvantages $(51.7 \%)$. This alone signifies that these farmers have no knowledge about soil biodiversity.

All farm activities take place on land. Any fault in soil properties interfere with crop production. Farmers were asked whether they were facing problems with their soils. $41.7 \%$ faced the problem of crop pests and diseases, $36.7 \%$ soil infertility, $3.3 \%$ soil erosion, $5 \%$ poor or low yields and $13.3 \%$ reported other ideas (Table 2).

These problems were due to poor farming practices and poor management or ignorance of farmers about better farming practices.

The farmers were further interrogated about whether their soils were fertile. Less than a half $(33.3 \%)$ had fertile soils while $66.7 \%$ had infertile soils (Table 2).
Table 2: Farmer's adoption indicators in Nagojje and Wakisi Sub County $(\mathrm{N}=60)$

\begin{tabular}{lcc}
\hline Variables/Indicators & Frequencies & Age (\%) \\
\hline $\begin{array}{l}\text { What decomposes plant and } \\
\text { animal remains }\end{array}$ & & \\
Soil living organisms & 14 & 23.3 \\
Rainfall and temperature & 16 & 26.7 \\
All the above & 10 & 16.7 \\
Not aware & 20 & 33.3 \\
Do you know soil living organisms & & \\
Yes & 20 & 33.3 \\
No & 40 & 66.7 \\
What would you do after knowing & & \\
organisms involved in rotting & & \\
process & & \\
Conserve them & 26 & 43.3 \\
Adapt the advice & 26 & 43.3 \\
Neglect them & 8 & 13.3 \\
Is your soil fertile & & \\
Yes & 21 & 35.0 \\
No & 39 & 65.0 \\
Indicators of soil fertility & & \\
Stunted growth & 17 & 28.3 \\
Yellowing of leaves & 11 & 18.3 \\
Crop vigor & 15 & 25.0 \\
Yielding capacity & 11 & 18.3 \\
Not aware & 6 & 10.0 \\
What soil related problems & & \\
do you face & & 4.3 \\
Pests and diseases & & \\
Soil infertility & 25 & 3.3 \\
Soil erosion & 3 & \\
Poor yields & & \\
Other ideas & & \\
\hline
\end{tabular}

Farmers determine their soil fertility by stunted growth of their crops $(28.3 \%)$, yellowing of leaves $(18.3 \%)$, high crop viguor (25\%), yielding capacity $(18.3 \%)$ and not aware $(10 \%)$. This justifies the fact that the farmers with their experience know symptoms of soil fertility by using morphological characteristics of crops but not soil properties analysis. They do not know that presence of soil living organisms like termites, etc. is a sign of fertility.

Table 3 showed that $43.3 \%$ apply fertilizer into their fields to boost fertility and $56.7 \%$ do not apply claiming that artificial fertilizers are expensive to buy and spoil their soils. It was also noted that $65 \%$ have livestock from which $40 \%$ apply fertilizer in form of animal dung. Less than $1 / 4$ (15\%) out those who have livestock just heap and abandon it and yet, they claim that their soils are infertile.

About $81.7 \%$ carry out crop rotation but do not know better sequences to follow. Most of them do not include fallow periods. $43.3 \%$ mulch their land using grass specie. They mulch specific crops including tomatoes and banana but not all crops. Most of them say that not every crop is mulched.

About $15 \%$ carry out composting meaning that $85 \%$ are ignorant about the technology. $76.7 \%$ plant their crops early in order to benefit from early rains. $65 \%$ carry out intercropping. Majority of them car you this practice because of little land while some of them want to get a variety of crops but not for its purpose. 
Res. J. Soil and Water Manage., 11 (1): 1-8, 2020

Table 3: Farming practices carried out by farmers in Nagojje and Wakisi Sub Counties $(\mathrm{N}=60)$

\begin{tabular}{|c|c|c|c|c|c|c|}
\hline Practice & Yes/No & Frequencies & Age $(\%)$ & Reason & Frequencies & Age (\%) \\
\hline \multirow[t]{3}{*}{ Land fallowing } & Yes & 30 & 50.0 & Soil fertility & 25 & 41.7 \\
\hline & No & 30 & 50.0 & Little land & 23 & 38.3 \\
\hline & & & & Not aware & 12 & 20.0 \\
\hline \multirow[t]{2}{*}{ Improved fallowing } & Yes & 3 & 5.0 & Soil fertility & 3 & 5.0 \\
\hline & No & 57 & 95.0 & Not aware & 57 & 95.0 \\
\hline \multirow[t]{4}{*}{ Fertilizer application } & Yes & 26 & 43.3 & Soil fertility & 5 & 8.3 \\
\hline & No & 34 & 56.7 & Expensive & 25 & 41.7 \\
\hline & & & & Spoil soil & 2 & 3.3 \\
\hline & & & & Not aware & 28 & 46.7 \\
\hline \multirow[t]{5}{*}{ Crop rotation } & Yes & 49 & 81.7 & Soil fertility & 11 & 18.3 \\
\hline & No & 11 & 18.3 & Proper crop growth & 14 & 23.3 \\
\hline & & & & Food variety & 11 & 18.3 \\
\hline & & & & Avoid diseases & 8 & 13.3 \\
\hline & & & & Not aware & 16 & 26.7 \\
\hline \multirow[t]{6}{*}{ Mulching } & Yes & 26 & 43.3 & Soil fertility & 1 & 1.7 \\
\hline & No & 34 & 56.7 & Soil moisture & 5 & 8.3 \\
\hline & & & & Prevent weeds & 3 & 6.7 \\
\hline & & & & Avoid rots & 6 & 10.0 \\
\hline & & & & Conserve biodiversity & 1 & 1.7 \\
\hline & & & & Not aware & 43 & 71.7 \\
\hline \multirow[t]{2}{*}{ Composting } & Yes & 10 & 16.7 & Make manure & 5 & 8.3 \\
\hline & No & 50 & 83.3 & Not aware & 49 & 81.7 \\
\hline \multirow[t]{5}{*}{ Early planting } & Yes & 46 & 76.7 & Early rains & 25 & 41.7 \\
\hline & No & 14 & 23.3 & Early harvests & 10 & 16.7 \\
\hline & & & & High yields & 6 & 10.0 \\
\hline & & & & Time & 3 & 6.7 \\
\hline & & & & Not aware & 15 & 25.0 \\
\hline \multirow[t]{5}{*}{ Intercropping } & Yes & 39 & 65.0 & Soil fertility & 1 & 1.7 \\
\hline & No & 21 & 35.0 & Proper crop growth & 3 & 5.0 \\
\hline & & & & Food variety & 2 & 3.3 \\
\hline & & & & Little land & 18 & 30.0 \\
\hline & & & & Not aware & 36 & 60.0 \\
\hline \multirow[t]{4}{*}{ Mixed cropping } & Yes & 19 & 31.7 & Soil fertility & 6 & 10.0 \\
\hline & No & 41 & 68.3 & Proper crop growth & 1 & 1.7 \\
\hline & & & & Food variety & 1 & 1.7 \\
\hline & & & & Not aware & 52 & 86.7 \\
\hline \multirow[t]{2}{*}{ Relay cropping } & Yes & 33 & 55.0 & Quick harvest & 7 & 11.7 \\
\hline & No & 27 & 45.0 & Not aware & 53 & 88.3 \\
\hline \multirow[t]{3}{*}{ Multistory cropping. } & Yes & 10 & 16.7 & Food variety & 3 & 6.7 \\
\hline & No & 50 & 83.3 & Provide shade & 2 & 3.3 \\
\hline & & & & Not aware & 54 & 90.0 \\
\hline \multirow[t]{2}{*}{ Cover cropping } & Yes & 8 & 13.3 & Avoid soil erosion & 2 & 3.3 \\
\hline & No & 52 & 86.7 & Not aware & 58 & 96.7 \\
\hline \multirow[t]{2}{*}{ Nurse cropping } & Yes & 3 & 5.0 & Support weak crops & 1 & 1.7 \\
\hline & No & 57 & 95.0 & Not aware & 59 & 98.3 \\
\hline \multirow[t]{3}{*}{ Shifting cultivation } & Yes & 17 & 28.3 & Enough land & 7 & 11.7 \\
\hline & No & 43 & 71.7 & Soil fertility & 3 & 6.7 \\
\hline & & & & Not aware & 49 & 81.7 \\
\hline
\end{tabular}

A few farmers practice mixed cropping, relay farming, multistory cropping, cover cropping, nurse cropping and shifting cultivation $(28.3,23.3,16.7,11.6$, 1.7 and $28.3 \%$, respectively). Most of those who do not practice claim that they are totally ignorant about the above technologies but would adopt if they are sensitized.

Almost all farmers faced the problem of pests and diseases $(98.3 \%)$, however, the biggest percentage leave these pests and some of them use pesticides but claim that pesticides are expensive to buy. Most farmers use hand hoe to open up their fields and during weeding which is good but during the process of cultivation, they disturb soil so much. This signifies that they do not know conservation tillage measures as shown by a $51 \%$. After harvesting, $40 \%$ leave crop trash in the field while some even burn them. This therefore, indicates that farmers have little knowledge about soil biodiversity conservation measures.

About $31.7 \%$ had access to soil biodiversity information while $68.3 \%$ didn't have. About $30 \%$ could get it from NGO's, $1.7 \%$ from agricultural officers while $68.3 \%$ had no idea. Over a half of farmers $(70 \%)$ never got advice on soil biodiversity, though they have ever heard about organizations that promote soil biodiversity. This shows that farmers lack the drive force to attend meetings and therefore do not have enough information (knowledge) about soil biodiversity conservation. 
Res. J. Soil and Water Manage., 11 (1): 1-8, 2020

Table 4: Farmer's activities in Nagojje and Wakisi Sub County $(\mathrm{N}=60)$

\begin{tabular}{lcr}
\hline Variables/Methods used & Frequencies & Age (\%) \\
\hline Pest management & 17 & 28.3 \\
Spray wit pest pesticides & 2 & 3.3 \\
Rotate crops & 6 & 10.0 \\
Remove affected plants & 10 & 16.7 \\
Use urine and ash & 25 & 41.7 \\
Leave them & & \\
Weeding & 57 & 95.0 \\
Hand hoeing & 2 & 3.3 \\
Use herbicides & 1 & 1.7 \\
Leave them & & \\
Land preparation & 58 & 96.7 \\
Hand hoeing & 2 & 3.3 \\
Use herbicides & & \\
Conservation tillage & 7 & 11.7 \\
Plant in holes & 1 & 1.7 \\
Contour ridging & 1 & 1.7 \\
Terracing & 51 & 85.0 \\
Not aware & & \\
Crop debris after harvesting & 9 & 15.0 \\
Burn it in field & 8 & 13.3 \\
Incorporate in soil & 2 & 3.3 \\
Feed to livestock & & 0.0 \\
Use them as mulches & 6 & 10.0 \\
Fuel & 11 & 18.3 \\
Leave them & 24 & 40.0 \\
Heap them & &
\end{tabular}

However, those who attended and implemented said that there was a significant increase in yields of high quality and that their soils remained good (Table 4).

Socio-economic factors affecting soil biodiversity conservation: Most male spouses were decision makers composing $81.7 \%$. This is because men are taken to be head of households culturally. About $76.7 \%$ produce enough food and very little for sale. This shows that most farmers are subsistent and a few are semi-commercial. According to results, $48.3 \%$ are subsistent, $48.3 \%$ are semi-commercial while $3.3 \%$ are commercial (Table 5).

About $71.7 \%$ of farmers use household labour, $20 \%$ use both household and hired while $8.3 \%$ hire labour. This reflects that most farmers are incapable of hiring labour and therefore produce many children to get the source of labour.

About 20\% face the problem of size of land, $16.7 \%$ do not have enough capital, $36.7 \%$ do not have both land and capital, $5 \%$ face the problem of inadequate labour while about $21.7 \%$ have other factors that limit their farm production such as entrepreneur, market, etc., this indicates that land is a major resource that should be taken care of.

Most farmers get their income from agricultural crops like cassava $(25 \%)$, coffee $(18.3 \%)$, banana $(10 \%)$, sugarcane $(8.3 \%)$, sweet potatoes $(1.7 \%)$ and others (30\%) while $6.7 \%$ get most of their income from other enterprise like business, fishing, etc., this indicates that farming is a major activity in Nagojje and Wakisi sub counties.
Table 5: Socio-economic factors affecting Soil biodiversity conservation in Nagojje and Wakisi Sub County $(\mathrm{N}=60)$

\begin{tabular}{|c|c|c|}
\hline Variables/Methods & Frequencies & Age (\%) \\
\hline \multicolumn{3}{|l|}{ Decision maker } \\
\hline Male & 49 & 81.700 \\
\hline Female & 11 & 18.300 \\
\hline \multicolumn{3}{|c|}{ What scale of farmer are you } \\
\hline Commercial & 3 & 5.000 \\
\hline Subsistent & 29 & 48.300 \\
\hline Semi commercial & 28 & 46.700 \\
\hline \multicolumn{3}{|l|}{ Source of labour } \\
\hline Household members & 43 & 71.700 \\
\hline Hired & 17 & 28.300 \\
\hline \multicolumn{3}{|l|}{ Source of income } \\
\hline Agriculture & 56 & 93.300 \\
\hline Other business & 4 & 6.700 \\
\hline \multicolumn{3}{|l|}{ Factors of production } \\
\hline Land & 12 & 20.000 \\
\hline Capital & 10 & 16.700 \\
\hline Labour & 3 & 5.000 \\
\hline All the above & 22 & 36.700 \\
\hline Others & 13 & 21.700 \\
\hline \multicolumn{3}{|l|}{ Marketing problems } \\
\hline Low prices & 30 & 50.000 \\
\hline Few market centers & 9 & 15.000 \\
\hline Poor transport & 1 & 1.700 \\
\hline All the above & 13 & 21.700 \\
\hline Other ideas & 7 & 11.700 \\
\hline \multicolumn{3}{|c|}{ Household expenditures } \\
\hline School fees & 21 & 35.000 \\
\hline Home basic needs & 33 & 55.000 \\
\hline Farm operations & 3 & 5.000 \\
\hline Others & 3 & 5.000 \\
\hline \multicolumn{3}{|c|}{ How do you spend on farm inputs } \\
\hline Seeds & 34 & 56.700 \\
\hline Fertilizers & 7 & 11.700 \\
\hline Labour & 5 & 8.300 \\
\hline Agrichemicals & 14 & 23.300 \\
\hline \multicolumn{3}{|c|}{ Sources of agriculture credit } \\
\hline Commercial Banks & 28 & 46.700 \\
\hline Farmer groups & 5 & 8.300 \\
\hline Not aware & 27 & 45.000 \\
\hline \multicolumn{3}{|c|}{$\begin{array}{l}\text { What is your strategy to } \\
\text { conserve soil biodiversity }\end{array}$} \\
\hline Education & 49 & 81.700 \\
\hline Demonstration farms & 3 & 5.000 \\
\hline No Idea & 8 & 13.333 \\
\hline
\end{tabular}

It was also deduced that apart from farming (93.3\%), these farmers get their side income from business, $5 \%$ from fishing, $13.3 \%$ provide labour to other farmers, $13.3 \%$ from other sources while $45 \%$ do not have the source of side income. This implies that capital limits farm production to greater extent.

When marketing farm produce, $50 \%$ face the problem of low prices offered to their produce, $15 \%$ have few market centers, $1.7 \%$ poor transport facilities, $21.7 \%$ both low prices and poor transport facilities while about $11.7 \%$ reported other problems. This showed that farmers have not commercialized agriculture because of poor marketing facilities.

It was also analyzed that $35 \%$ spend their income by paying school fees for their children, $55 \%$ buy food and 
Res. J. Soil and Water Manage., 11 (1): 1-8, 2020

\begin{tabular}{|c|c|c|c|c|c|c|}
\hline Models & $\mathrm{B}$ & SE & Wald & $\mathrm{df}$ & Sig. & $\operatorname{Exp}(B)$ \\
\hline \multicolumn{7}{|l|}{ Step 1 (a): } \\
\hline Education level & 0.213 & 0.093 & 5.268 & 1 & 0.022 & 1.237 \\
\hline Members of household & 0.236 & 0.128 & 3.399 & 1 & 0.065 & 1.266 \\
\hline Age & 0.000 & 0.036 & 0.000 & 1 & 0.995 & 1.000 \\
\hline Land size & -0.011 & 0.065 & 0.026 & 1 & 0.871 & 0.990 \\
\hline Period in farming & -0.003 & 0.038 & 0.008 & 1 & 0.927 & 0.997 \\
\hline Constant & -3.632 & 1.46 .0 & 6.192 & 1 & 0.013 & 0.026 \\
\hline
\end{tabular}

A variable's entered on step 1; Education level; Members of household; Age, Land size; Period in Farming

home utensils (including; soap, fuel, medicine, etc.), $5 \%$ farm operations while $5 \%$ spend their income in other ways. On farm inputs, $56.7 \%$ buy seeds, $11.7 \%$ buy fertilizer, $8.3 \%$ pay labour, $23.3 \%$ buy pesticides and herbicides. This is a clear indication that most farmers carry out the activity to sustain the livelihood of their families, hence, subsistent.

About $46.7 \%$ could get credit from commercial banks to boost their farm production. About $8.3 \%$ could get credit from farmer groups while $45 \%$ did not know any source of credit. About $81.7 \%$ suggested that education would give them conservation knowledge about the technology. Education would sensitize them about advantages of conserving soil living organisms. About 5\% suggested that use of demonstration farms could encourage them to adopt the technology, since, farmers believe by seeing, $13.3 \%$ had no ideas.

Logistic model estimates: A binary logit model of logistic regression model in statistical package of social sciences was used to determine factors that could enhance adoption of soil biodiversity conservation measures. Results in Table 6 show that education and members of household were statistically significant at $10 \%$ level.

Education was significant because it gives knowledge to farmers about soil biodiversity that will help them to understand the advantages of conserving it, make proper decisions, adapt the technology and help them to search or be able to make research about the same technology and other technologies. Therefore, education is said to be a predisposing factor for adoption of soil biodiversity conservation measures. It is widely known that literate farmers are more disposed to understand new ideas and concepts provided by extension workers and other informants.

Members of household were also significant because it is the major source of labour input in the agriculture sector, especially in Uganda.

\section{CONCLUSION}

It is important to remember that agriculture largely depend on biodiversity. Also important is that the population of Uganda is multiplying day by day there by creating pressure on agricultural soils for settlement, etc., leading to environmental degradation and hence global warming. Results showed that most farmers in Wakisi and Nagojje sub counties did not have sufficient information about soil biodiversity conservation. Most of farmers suggested that exposure to education would predispose them to adopt the technology. Results from logistic regression model indicated that education and members in household had significant impacts on adoption of soil biodiversity. As evident, education increases literacy among farmers about a new technology and this enhances their ability to adopt new technologies. It is therefore crucial to present concerns on our environment. Soil biodiversity conservation is the foundation for total environmental conservation.

\section{RECOMMENDATIONS}

The efforts of the government of Uganda for bringing education for all and initiating the Functional Adult Literacy programme (FAL) should be applauded however these efforts should come up with clear policies and other approaches to educate elders and farmers in particular such that these farmers can easily perceive, adapt, implement and are able to make research on agricultural related disciplines hence agricultural modernization.

Relevant to the above, the government should at all time support organizations like BGBD-Makerere University and other institutions concerned about developmental technologies most especially in agriculture sector.

Proper teaching methods should always be chosen most especially. for a new technology. For example, demonstration plots, field visits seem to provide practical experience to most farmers and can quickly enhance adoption. This is because most farmers believe by seeing such that they can be able to determine whether a new technology will work. This education will provide sufficient information about conservation measures and the advantages/benefits of conserving soil biodiversity.

Provision of incentives to farmers can indeed show considerable influence on adoption. These incentives can be inform of subsidized prices of agricultural inputs, direct payments to enable farmers be facilitated with the requirements of a technology, etc.

These incentives polish up farmer's perception of the technology, since, they think that they are given at a free or fair cost. 
Making farmers as part of the Programme is also important. Once farmers are involved in the technology, they can present their concerns about it and possible solutions are developed together. Under this point, one should note that farmers can only adopt a technology that suit or fulfills their needs a reason why it is important to involve them right from the development stage.

Members in household were significant because they are the main source of labour at subsistence level. There should be the introduction of simple tools and equipments to cater for this gap. These tools should be given to farmers at subsidized prices.

However, further research should be done about the relationship between termites and maize production and their management.

\section{REFERENCES}

01. Sileshi, G., F.K. Akinnifesi, O.C. Ajayi, S. Chakeredza, S. Mng'omba and B.I. Nyoka, 2008. Towards sustainable management of soil biodiversity in agricultural landscapes in Africa. Biodivers., 9: 64-67.

02. Blouin, M., M.E. Hodson, E.A. Delgado, G. Baker and L. Brussaard et al., 2013. A review of earthworm impact on soil function and ecosystem services. Eur. J. Soil Sci., 64: 161-182.

03. Hole, D.G., A.J. Perkins, J.D. Wilson, I.H. Alexander, P.V. Grice and A.D. Evans, 2005. Does organic farming benefit biodiversity. Biol. Conserv., 122: 113-130.

04. Atina, D., 2007. Soil health and biodiversity in practice: Harnessing biology, ecology and resiliency on the farm. Midwest Organic and Sustainable Education Service, Spring Valley, Wisconsin.

05. Montanarella, L., 2008. Towards protecting soil biodiversity in Europe: The EU thematic strategy for soil protection. Biodivers., 9: 75-77.

06. Symondson, W.O., 2012. The Molecular Revolution: Using Polymerase Chain Reaction Based Methods to Explore the Role of Predators in Terrestrial Food Webs. In: Biodiversity and Insect Pests: Key Issues for Sustainable Management, Gurr, G.M., S.D. Wratten, W.E. Snyder and D.M.Y. Read (Eds.). John Wiley \& Sons, Ltd., Hoboken, New Jersey, USA., pp: 166-184.

07. Isenring, R., 2010. Pesticides and the loss of biodiversity. Pesticide Action Network Europe, London, UK.

08. Thrupp, L.A., 2000. Linking agricultural biodiversity and food security:The valuable role of agrobiodiversity for sustainable agriculture. Int. Affairs, 76: 265-281.

09. Temu, E.J., 2013. Adoption of sustainable land management technologies: Revisiting impact to community livelihood in West Usambara mountains, Tanzania. Ph.D. Thesis, Sokoine University of Agriculture, Morogoro, Tanzania.
10. UBOS., 2009. Higher local government statistical abstract Mukono district. Uganda Bureau of Statistics, Kampala, Uganda.

11. Violet, N.G., C.K.K. Gachene, J.N. Ngugi, E.G. Thuranira and M.W. Baaru, 2002. Adoption and opportunities for improving soil and water conservation practices in Kathekakai settlement scheme, Machakos District. Kenya Agricultural Research Institute (KARI), Nairobi, Kenya.

12. Nkonja, E., 2002. Soil Conservation Practices and Non-Agricultural Activities in Southwestern Highlands of Uganda. In: Policies for Improved Land Management in Uganda, Nkonya, E., S. Dick and P. John (Eds.). Second EPTD National Workshop, Washington, D.C., USA., pp: 1-31.

13. Knowler, D. and B. Bradshaw, 2007. Farmers adoption of conservation agriculture: Review and synthesis of recent research. Food Policy, 32: 25-48.

14. Kammer, S., 2014. Factors influencing the adoption of soil and water conservation technologies: A case study of two farming communities in rural Ethiopia. Masters Thesis, University of Washington, Washington, USA.

15. Bekele, W., 2003. Economics of soil and water conservation: The theory and empirical application to subsistence farming in the eastern Ethiopia high lands. Ph.D. Thesis, Swedish University of Agricultural Sciences, Uppsala.

16. Wauters, E., 2006. The adoption of soil conservation measures in Belgium. An application of the theory of planned behaviour. Commun. Agric. Applied Biol. Sci., 71: 29-35.

17. FAO., 2013. The economics of conservation agriculture. FAO., Rome, Italy.

18. Bayard, B., C.M. Jolly and D.A. Shannon, 2006. The adoption and management of soil conservation practices in Haiti: The case of rock walls. Agric. Econ. Rev., 7: 28-39.

19. Nkegbe, P.K., B. Shankar and M.G. Ceddia, 2011. Smallholder adoption of soil and water conservation practices in Northern Ghana. Proceedings of the 2011 International Congress, August 30-September 2, 2011, Zurich, Switzerland, pp: 1-13.

20. Melese, M. and R.U. Reddy, 2016. Adoption of soil and water conservation practices among smallholder farmers: The case of Boloso sore Woreda, Wolaita zone, SNNPR, Ethiopia. Ph.D. Thesis, Haramaya University, Dire Dawa, Ethiopia.

21. Otieno, A.C., M. Buyinza, R.A., Kapiyo and B.O. Oindo, 2013. Local communities and collaborative forest management in West Bugwe forest reserve, Eastern Uganda. Environ. Res. J., 7: 69-78.

22. Malezieux, E., Y. Crozat, C. Dupraz, M. Laurans and D. Makowski et al., 2009. Mixing plant species in cropping systems: Concepts, tools and models: A review. Agron. Sustain. Dev., 29: 43-62. 